\title{
Entry, Descent, and Landing With Propulsive Deceleration
}

Bryan Palaszewski

Glenn Research Center, Cleveland, Ohio 


\section{NASA STI Program . . . in Profile}

Since its founding, NASA has been dedicated to the advancement of aeronautics and space science. The NASA Scientific and Technical Information (STI) program plays a key part in helping NASA maintain this important role.

The NASA STI Program operates under the auspices of the Agency Chief Information Officer. It collects, organizes, provides for archiving, and disseminates NASA's STI. The NASA STI program provides access to the NASA Aeronautics and Space Database and its public interface, the NASA Technical Reports Server, thus providing one of the largest collections of aeronautical and space science STI in the world. Results are published in both non-NASA channels and by NASA in the NASA STI Report Series, which includes the following report types:

- TECHNICAL PUBLICATION. Reports of completed research or a major significant phase of research that present the results of NASA programs and include extensive data or theoretical analysis. Includes compilations of significant scientific and technical data and information deemed to be of continuing reference value. NASA counterpart of peer-reviewed formal professional papers but has less stringent limitations on manuscript length and extent of graphic presentations.

- TECHNICAL MEMORANDUM. Scientific and technical findings that are preliminary or of specialized interest, e.g., quick release reports, working papers, and bibliographies that contain minimal annotation. Does not contain extensive analysis.

- CONTRACTOR REPORT. Scientific and technical findings by NASA-sponsored contractors and grantees.
- CONFERENCE PUBLICATION. Collected papers from scientific and technical conferences, symposia, seminars, or other meetings sponsored or cosponsored by NASA.

- SPECIAL PUBLICATION. Scientific, technical, or historical information from NASA programs, projects, and missions, often concerned with subjects having substantial public interest.

- TECHNICAL TRANSLATION. Englishlanguage translations of foreign scientific and technical material pertinent to NASA's mission.

Specialized services also include creating custom thesauri, building customized databases, organizing and publishing research results.

For more information about the NASA STI program, see the following:

- Access the NASA STI program home page at http://www.sti.nasa.gov

- E-mail your question to help@sti.nasa.gov

- Fax your question to the NASA STI Information Desk at 443-757-5803

- Phone the NASA STI Information Desk at 443-757-5802

- Write to: STI Information Desk NASA Center for AeroSpace Information 7115 Standard Drive Hanover, MD 21076-1320 
NASA/TM-2012-217745

AIAA-2009-521

\section{Entry, Descent, and Landing With Propulsive Deceleration}

\section{Bryan Palaszewski}

Glenn Research Center, Cleveland, Ohio

Prepared for the

47th Aerospace Sciences Meeting

sponsored by the American Institute of Aeronautics and Astronautics

Orlando, Florida, January 5-8, 2009

National Aeronautics and

Space Administration

Glenn Research Center

Cleveland, Ohio 44135 
This work was sponsored by the Fundamental Aeronautics Program at the NASA Glenn Research Center.

Level of Review: This material has been technically reviewed by technical management.

Available from

NASA Center for Aerospace Information

7115 Standard Drive

Hanover, MD 21076-1320
National Technical Information Service 5301 Shawnee Road Alexandria, VA 22312

Available electronically at http://www.sti.nasa.gov 


\title{
Entry, Descent, and Landing With Propulsive Deceleration
}

\author{
Bryan Palaszewski \\ National Aeronautics and Space Administration \\ Glenn Research Center \\ Cleveland, Ohio 44135
}

\begin{abstract}
The future exploration of the Solar System will require innovations in transportation and the use of entry, descent, and landing (EDL) systems at many planetary landing sites. The cost of space missions has always been prohibitive, and using the natural planetary and planet's moons' atmospheres for entry, descent, and landing can reduce the cost, mass, and complexity of these missions. This paper will describe some of the EDL ideas for planetary entry and survey the overall technologies for EDL that may be attractive for future Solar System missions.
\end{abstract}

\section{Introduction}

Entry, descent, and landing are a series of events needed to safely land on the surface of another body in the solar system which possesses an atmosphere. Mars, Venus, the outer planets, and the outer planet moon, Titan, all require technologies that will protect the spacecraft from the high temperatures created during the initial hypersonic entry, and finally slow the vehicle from that hypersonic speed into the supersonic regime, then to subsonic and to the final touchdown. In the outer planet atmospheres, the final landing would be replaced with a buoyancy system such as an airship, balloon, or an aircraft.

\section{Historical Missions}

Landing space vehicles on other planetary bodies is a challenge in propulsion, precision control, and guidance. As there is no substantial atmosphere surrounding Earth's Moon, the lunar landings of robotic Surveyor and human Apollo missions used propulsion for the entire descent. The same was true for the successful Luna and Lunakhod flights of the U.S.S.R. For Venus with its dense atmosphere, landing vehicles used aeroshell and parachute combinations, with crushable elements (balsa wood, etc.) to absorb the final landing energy. On Mars, the landing vehicles became more massive and complex (Viking, Pathfinder, Mars Exploration Rovers (MER)), and the since the atmosphere was very thin, the final landing systems was a combination for aeroshell, parachute and retro rockets. To allow landing in more rugged areas of Mars, an additional airbag system was devised for the Pathfinder and MER landers to assure a successful landing in rock strewn sites. Figure 2 depicts the Mars Science Laboratory landing sequence. A rocket powered descent is essential for softly landing a large payload.

\section{Mars}

Several EDL configurations are under assessment for Mars. Figure 1 presents the historical comparison of the USA Mars entry capsules (Ref. 1). The typical $70^{\circ}$ cone angle for these configurations was selected for high stability and high drag. As the planet's atmosphere is quite thin, the blunt body can provide the needed drag for relatively small payloads of up 1 metric ton. As the mass of the lander vehicle increases, a different set of EDL technologies are required. Based on past studies (Refs. 2 and 3), parachutes are impractical for vehicles with lander masses of over 20 metric tons; the parachutes are too big to deploy effectively and reliably. Therefore, a combination of inflatable decelerators and propulsive deceleration has been suggested. Many past studies have investigated landing on Mars with aerodynamic systems (Refs. 4 to 9). However, the most recent studies imply that the past studies assumptions were too optimistic and are in need of revision to assure success. 


\section{Current Planning}

The Supersonics Project in the NASA Fundamental Aeronautics Program is supporting research in areas to allow effective design of future High Mass Mars Entry Systems (HMMES). Under HMMES, there are five areas of research: Static Aerodynamic Performance Prediction, Dynamic Performance Evaluation, Computational Fluid-Structures Interaction Methods, Decelerator Testing, and Propulsive deceleration.

\section{Static Aerodynamic Performance Prediction}

In this research area, there are efforts to computationally simulate the fluid dynamics of entry vehicles, the interactions of wakes with static parachutes or other decelerators, and the loads on and the performance of the decelerator system. Experimental studies will use these simulations for design improvements.

\section{Dynamic Performance Evaluation}

There will also be efforts to develop an integrated conceptual analysis capability for analyzing and comparing potential EDL systems for large payloads. Variable-fidelity discipline analyses, including aerodynamics, trajectory, structures, propulsion, mass estimation, and heat transfer, will be incorporated into a computational tool to allow assessment of various system architectures.

\section{Computational Fluid-Structures Interaction Methods}

This research effort will extend the static aerodynamic calculations of the Dynamic Performance Evaluation element to calculations of the unsteady aerodynamics of a vehicle/decelerator system, and to develop tools for computing the interactions between the fluid mechanics and the structural response of flexible parachutes and other decelerators.

\section{Decelerator Testing}

Develop ground and flight test capabilities for evaluations of various supersonic aerodynamic decelerator concepts. This research will focus on inflatable decelerators for the supersonic flight regime and also investigate the hand off from the hypersonic flight speeds to supersonic flight.

\section{Propulsive Deceleration}

Investigate novel experimental approaches for using rocket propulsion for decelerating an entry vehicle through the supersonic speed regime in a planetary atmosphere. Under the auspices of Propulsive Deceleration, the elements of the planned experimental and computational program include:

1. Supersonic Aerodynamics About The Nozzles During Ignition,

2. Flow Instabilities During The Ignition Process,

3. Covers For Engines, Including Purge Gases, To Effect Ignition In Vacuum,

4. Large Expansion Ratio Nozzle Effects On Aerodynamics And Ignition Transients (Shock Structure(s) In Nozzle), Heat Transfer In Nozzles, Chambers, and Landing Site,

5. Exhaust Plume Jet And Surface Interactions During Landing,

6. Evaluation of propellant selection and propulsion modes, including $\mathrm{O}_{2} / \mathrm{H}_{2}$, and $\mathrm{O}_{2} / \mathrm{CH}^{4}$ (methane), and $\mathrm{O}_{2} / \mathrm{CO}$ (carbon monoxide). The effects of in-situ resource utilization (ISRU) on propellant combination selection will be evaluated. 
The testing will be conducted in the NASA 1- by 1-Foot Supersonic Wind Tunnel (SWT) on small scale engines to demonstrate techniques for effective ignition and start up transients. A more detailed description of the six areas is provided below.

1. Supersonic aerodynamics about nozzles during ignition:

We plan to assemble and test fire a subscale rocket engine in a wind tunnel using a relevant Mars environment. The resulting data will be analyzed and correlated with ignition conditions and external flow conditions to create a database on the flow field about the nozzle during entry.

2. Flow instabilities during the ignition process:

Nozzle flow instabilities during the entry conditions will impact the ignition process. Flow instabilities will be measured to develop a database of nozzle flow stability regimes. The measured nozzle flow instabilities will be analyzed and correlated to the external flow conditions about the nozzle.

3. Engine covers to effect ignition in a vacuum:

Successful rocket ignition is often affected by vacuum levels. Wind tunnel testing will measure the ignition limits for purged and unpurged engines during entry conditions. The resulting data will define purge gas concentrations required for effective ignition and whether engine covers may be required.

As the vehicle descends through the atmosphere, the vehicle will decelerate to supersonic speeds. The planned inflatable aerodynamic decelerators are predicted to allow the vehicle to slow to Mach 2 or 3 before the retro propulsion or propulsive deceleration system is ignited. The engines for the deceleration are protected from the entry heating by the main aeroshell, and to be effective, the engines will likely need some extendible nozzle to protrude through the aeroshell.

4. Large expansion ratio nozzle effects (fluid-structure interactions):

Wind tunnel testing will measure the external aerodynamics and ignition transients (shock structure in the nozzle flow) of large expansion ratio nozzles. Resulting data will be analyzed and correlated with flow instabilities to create a database of external aerodynamics and ignition transients of these large expansion ratio nozzles that can be applied to EDL mission profiles.

With the potentially large expansion ratio nozzles protruding from the aeroshell, additional heat transfer enhancement will occur due to rocket plume recirculation or base heating (Fig. 4, Ref. 24). Issues associated with improving and enhancing the heat shield, such as shock-shock interactions, where enhanced heat transfer will occur, are to be investigated.

As the EDL vehicle decelerates, the shock structure of the atmospheric flow field will begin interacting violently with the retro propulsion system exhaust plumes. Figure 3 illustrates some of the effects of the rocket - aeroshell flow field. Localized higher than normal heating will occur where these shocks touch the aeroshell and therefore enhanced heat shield designs will be needed to protect the vehicle from these localized hot spots. 
5. Heat transfer in nozzles and chambers:

We plan to measure the nozzle and chamber heat transfer environment during EDL and at landing site conditions. Wind tunnel tests will be conducted to measure these heat transfer conditions over the EDL condition range. Resulting data will be analyzed and correlated to nozzle flow instabilities and the external aerodynamic environment.

6. Evaluation of propellant selection and propulsion modes:

We will evaluate the use of $\mathrm{O}_{2} / \mathrm{H}_{2}$ (hydrogen), $\mathrm{O}_{2} / \mathrm{CH}^{4}$ (methane), and $\mathrm{O}_{2} / \mathrm{CO}$ (carbon monoxide) as propellants for EDL propulsive deceleration requirements. The effects of in-situ resource utilization (ISRU) on propellant combination selection will be reviewed.

\section{EDL Links to Other Future Space Missions}

\section{Exploration Systems and Space Operations Mission Directorates Benefits}

Improved rocket exhaust plume modeling for all space vehicles will be derived from EDL technologies. Detailed studies and experiments focused on the plume effects on vehicle heating during entry and the main engine heating effects during descent and landing will be a major benefit to other space operations program, such as the NASA Crew Exploration Vehicle.

\section{Science Mission Directorate Benefits}

With EDL technologies, there will be improved lander protection from rock-strewn surfaces, which will aid precision landing technologies. With effective rocket engine design, EDL technologies can allow for improved payload protection after landing, mitigating dust on spacecraft surfaces. Lunar, Mars, and outer planet moon landing dust mitigation strategies can be investigated. With lunar and Mars missions, dust has been a serious issue in the obscuration of the landing site and potential damage to space suit and rotating components.

\section{The Outer Solar System}

Our Outer Solar System is composed of gas giant planets, moons, and many smaller bodies than exciting targets for exploration (Refs. 9 to 25). The Galilean moons of Jupiter have been studied intensively by the Galileo spacecraft, and the implications of these studies imply that oceans of water may exist below these moons' icy surfaces (Refs. 11 to 13). A series of EDL technologies may be used to enter Jupiter's atmosphere, slow a higher payload mass vehicle into orbit, and allow more effective exploration of those moons. At Saturn, Titan is also a fascinating target for exploration, and its relatively thick and cold atmosphere can allow the use of aerocapture and EDL technologies for braking into orbit about Saturn and landing on Titan, or both. With EDL technologies, aerocapture at these outer planets can be accomplished and the planetary landing may also be allowed with the same or a related deceleration system: either propulsive or aerodynamic.

Preliminary designs from past studies have identified the technologies are most attractive for use of EDL for these missions. Other options for atmospheric flight are possible for exploration and exploitation, including flight in planetary atmospheres with advanced fuels (Refs. 9 and 21 to 25). Outer planet mining options using entry and descent techniques have been assessed in References 21 to 23 . 


\section{Outer Planet Flagship Missions}

A series of outer planet flagship missions are also being assessed for selection. These include a Titan orbiter or Titan Balloon (at Saturn), Enceladus mission (at Saturn), Europa mission (at Jupiter), and a Jupiter survey mission. Each of these missions could employ aspects of the EDL technology being developed. Though landing on the outer planets is not an option, using the entry and descent technologies for atmospheric braking and exploration of a planet's atmosphere is an option for future uses of this basic aerodynamic research. Figure 5 (Ref. 25) shows an aerocapture vehicle designed for Neptune called the ellipsled. Its name is derived from the elliptical cross sectional shape and the fact that the spacecraft is stored inside the aeroshell as if it were attached to a sled (or toboggan).

\section{Atmospheric Mining in the Outer Solar System}

Mining of the outer planet atmospheres is a special case of planetary resource utilization. Reference 23 summarizes the nature of the gases in the outer planet atmospheres. While there are enormous caches of fuel in those atmospheres, the gravity of the planets makes for a high energy set of maneuvers to enter orbit, enter the atmosphere, persist there for the mining operation, and emerge from the atmosphere with the mined fuel. Therefore, specially designed space and aerospace vehicle vehicles will be needed to wrest the gases from the powerful gravity wells of these giant planets. To reduce the orbit insertion delta- $\mathrm{V}$, previous mission studies and planetary missions have typically placed their space vehicles into highly elliptical orbits. Often, flybys of the planets moons are used to pump (or increase the energy of) the orbit and allow a full tour of the system of moons about the gas giants. Attaining a low orbit about the gas giants takes a fairly high delta- $\mathrm{V}$, a value that is often beyond most previously studied mission capabilities.

Atmospheric mining of the outer planets will require a number of spacecraft and many complex maneuvers to wrest fuels from their powerful gravity wells. Several different mining scenarios were investigated: cruisers, balloons, and scoopers. Given the complexity of the missions discussed and the delta-V required for mining, the cruiser- and balloon-borne mining scenarios are the most promising for future study.

Cruisers have the advantage of operating in the atmosphere at subsonic speeds, which eases the liquefaction requirements for mining. Also, the stresses on the vehicle seem the most benign of all of the mining vehicles. The cruiser idea may be the most attractive scenario for the longer term missions. The cruiser will likely use the planetary atmosphere for fuel (for a nuclear "airbreathing” engine) and capture and liquefy the needed gases from the atmosphere as well. The cruiser may exit the atmosphere and be refitted or resupplied (with delivery capsules, other consumables, replacement units, etc.) from orbital assets.

Balloons have been proposed in the past as viable mining platforms. However, the lifetime of balloon systems, especially higher temperature balloons, will be a limiting factor in balloon-borne mining scenario. Shorter life missions will be more suited to the balloon miner. Typical balloon lifetime for Earth exploration is usually in the 10's to perhaps $100 \mathrm{hr}$. While a fascinating option, the scooper miners will likely be used for short and limited forays into the atmosphere.

The EDL research will be important in allowing these mining vehicles to enter and re-enter the atmospheres of the outer planets. Entry into the outer planet atmospheres will require specialized developments as the temperatures there are cryogenic and special protection will be required from the hydrogen and helium atmospheric gases.

Mining the planets will likely unlock new capabilities to explore and exploit the solar system. The initial steps in pursuing in-situ resource utilization will allow new visions for energy sources for Earth, solar systems spacecraft, and perhaps humankind's first step into interstellar space. The technologies for entry and descent can lead the way. 


\section{Concluding Remarks}

Entry, descent, and landing technologies are under development for the high mass Mars Entry system (HMMES). Many investigations of aerodynamic deceleration for the outer planets have been conducted as well. The challenges for EDL are numerous, especially for inflatable decelerator and the interactions that will occur with propulsive deceleration retro propulsion. The high velocities involved in entry and descent will require high temperature materials that are flexible for folding into a small volume, but reliable when they are deployed to their full diameter.

Many exciting possibilities are foreseen for outer planet exploration and exploitation. The resources of the outer planets may allow fueling of nuclear fusion vehicles and other power plants that may be the engine for all of Earth's energy. Wresting fuels such as hydrogen and helium 3 from the gas giant planets may be a critical element of outer planet exploration and also flight to the nearby stars.

\section{References}

1. Karl T. Edquist, Artem A. Dyakonov, Michael J. Wright, and Chun Y. Tang, "Aerothermodynamic Environments Definition for the Mars Science Laboratory Entry Capsule,” AIAA-2007-1206, 45th AIAA Aerospace Sciences Meeting and Exhibit, Reno, Nevada, 8-11 January 2007.

2. Karl T. Edquist and Stephen J. Alter, "Computational Aeroheating Predictions for Mars Lander Configurations,” AIAA-2003-3639, 36th AIAA Thermophysics Conference, Orlando, Florida, 23-26 June 2003.

3. Philip O. Jarvinen and Richard H. Adams, “The Aerodynamic Characteristics of Large Angled Cones With Retrorockets: Final Report,” Contract No. NAS 7-576, Prepared by MITHRAS, Report number MC 70 - 3001 - R2 (BNY), February 1970.

4. Palaszewski, B., Frisbee, R., “Advanced Propulsion for the Mars Rover Sample Return Mission,” AIAA PAPER 88-2900, Jul 01, 1988.

5. Frisbee, R.H., "Mass and Power Estimates for Mars In-Situ Propellant Production Systems,” AIAA PAPER 87-1900, Jun 01, 1987.

6. Hepp, Aloysius F., Linne, Diane L., Landis, Geoffrey A. Inc., Groth, Mary F. Colvin, James E., "Production and Use of Metals and Oxygen for Lunar Propulsion," NASA-TM-105195, AIAA PAPER 91-3481, Jan 01, 1991.

7. Linne, Diane L., and Meyer, Michael L., “Technical prospects for utilizing extraterrestrial propellants for space exploration,” NASA-TM-105263 presented at the 42nd International Astronautical Congress, Montreal, Quebec, 5-11 Oct. 1991; sponsored by International Astronautical Federation International Astronautical Congress Montreal, Quebec, 5-11 Oct. 1991.

8. Rice, E., "Final Report on Advanced System Concept for Total ISRU Based Propulsion and Power Systems for Unmanned and Manned Mars Exploration,” Orbital Technologies Corporation, National Institute for Advanced Concepts (NIAC) Phase II Contract, Research Grant 07600-041, OTC-GS0096-FR-2002-1, Universities Space Research Association (USRA), 30 April 2002. Also, see: http://www.niac.usra.edu/files/studies/final_report/pdf/395Rice.pdf

9. Powell, Paniagua, Maise, Ludewig, Todosow Exploration of Jovian Atmosphere Using Nuclear Ramjet Flyer, IAF 98-S.6.08, PUR-4, 24 July '98. Also, see: http://www.newworlds.com/reports/ PUR-4.PDF

10. John Paniagua, James R. Powell and George Maise, "Europa Sample Return Mission Utilizing High Specific Impulse Propulsion Refueled with Indigenous Resources,” Report No. PUR. 21, PHASE I. FINAL REPORT, Plus Ultra Technologies, Inc., National Institute for Advanced Concepts (NIAC) Phase I Grant 07600-077, Prime Contract Number NAS5-98051, November 30, 2001. Also see: http://www.niac.usra.edu/files/studies/final_report/pdf/638Paniagua.pdf

11. V.I. Shematovich and R.E. Johnson, "NEAR-SURFACE OXYGEN ATMOSPHERE AT EUROPA,” Adv. Space Res. Vol. 27, No. 11, pp. 1881-1888, 2001, Pergamon Press, (C 2001 COSPAR. Published by Elsevier Science Ltd., Printed in Great Britain. 
12. Christopher F. Chyba and Cynthia B. Phillips, "Possible ecosystems and the search for life on Europa,” PERSPECTIVE, Proceedings of the National Academy of Sciences (PNAS), USA, January 30, 2001 u vol. 98, no. 3, pp. 801-804.

13. Thomas B. McCord, Gary B. Hansen, and Charles A. Hibbitts, "Hydrated Salt Minerals on Ganymede’s Surface: Evidence of an Ocean Below,” Science, 2001 May 25; 292: 1523-1525.

14. T.B. McCord, R.W. Carlson, W.D. Smythe, G.B. Hansen, R.N. Clark, C.A. Hibbitts, F.P. Fanale, J.C. Granahan, M. Segura, D.L. Matson, T.V. Johnson, and P.D. Martin, "Organics and Other Molecules in the Surfaces of Callisto and Ganymede," Science, 1997 October 10; 278: 271-275.

15. Adam P. Showman and and Renu Malhotra, "The Galilean Satellites," Science 1999 October 1; 286: 77-84.

16. R. Carlson, W. Smythe, K. Baines, E. Barbinis, K. Becker, R. Burns, S. Calcutt, W. Calvin, R. Clark, G. Danielson, A. Davies, P. Drossart, T. Encrenaz, F. Fanale, J. Granahan, G. Hansen, P. Herrera, C. Hibbitts, J. Hui, P. Irwin, T. Johnson, L. Kamp, H. Kieffer, F. Leader, E. Lellouch, R. Lopes-Gautier, D. Matson, T. McCord, R. Mehlman, A. Ocampo, G. Orton, M. Roos-Serote, M. Segura, J. Shirley, L. Soderblom, A. Stevenson, F. Taylor, J. Torson, A. Weir, and P. Weissman, "Near-Infrared Spectroscopy and Spectral Mapping of Jupiter and the Galilean Satellites: Results from Galileo's Initial Orbit,” Science, 1996 October 18; 274: 385-388.

17. R.W. Carlson, M.S. Anderson, R.E. Johnson, W.D. Smythe, A.R. Hendrix, C.A. Barth, L.A. Soderblom, G.B. Hansen, T.B. McCord, J.B. Dalton, R.N. Clark, J.H. Shirley, A.C. Ocampo, and D.L. Matson, "Hydrogen Peroxide on the Surface of Europa," Science 1999 March 26; 283: 20622064.

18. Amanda E. Lowell, Kah-Siew Ho, and Robert A. Lodder, "Remote Hyperspectral Imaging of Endolithic Biofilms Using a Robotic Probe,” Contact in Context:v1i1/planetprobe, Copyright 2002 Contact in Context. This article is available at http://cic.setileague.org/v1i1/planetprobe.pdf

19. Frank D. Carsey, Gun-Shing Chen, James Cutts, Lloyd French, Roger Kern, A., Lonne Lane, Paul Stolorz, and Wayne Zimmerman, and Phil Ballou Exploring Europa's Ocean: A Challenge For Marine Technology Of This Century,” JPL 00-0221, Marine Technology Society Journal, Deep Ocean Frontiers Issue, Washington D.C., USA, 2000. http://techreports.jpl.nasa.gov/2000/000221.pdf

20. David F. Woerner, "Revolutionary Systems And Technologies For Missions To The Outer Planets," Advanced Scientific Space Missions, Aosta, Italy, June 29-July 1, 1998. http://techreports.jpl.nasa.gov/1998/98-0522.pdf

21. Palaszewski, B., “Atmospheric Mining in the Outer Solar System: Mission Scenarios and Options for In-Situ Resource Utilization,” AIAA 2007-5598, July 2007.

22. Palaszewski, B., “Atmospheric Mining in the Outer Solar System: Vehicle Design Issues,” AIAA 2006-5222, July 2006.

23. Palaszewski, B., “Atmospheric Mining in the Outer Solar System,” AIAA 2005-4319, July 2005.

24. Andrews, D.G. (Boeing Co., Seattle, Wash.) Bloetscher, F. (Goodyear Aerospace Corp., Akron, Ohio), “Aerobraked Orbital Transfer Vehicle Definition,” AIAA-1981-279, January 1981, 9 p.

25. R. Dyke, Swales Aerospace, Hampton, VA, and G. Hrinda, NASA Langley Research Center, Hampton, VA, “Structural Design for A Neptune Aerocapture Mission,” AIAA-2004-5179, August, 2004. 


\begin{tabular}{|c|c|c|c|c|c|}
\hline & Viking $1 / 2$ & Pathfinder & MER A/B & Phoenix & MSL \\
\hline Diameter, m & 3.5 & 2.65 & 2.65 & 2.65 & 4.5 \\
\hline Entry mass, kg & 930 & 585 & 840 & 602 & $>3000$ \\
\hline Landed mass, $\mathrm{kg}$ & 603 & 360 & 539 & 364 & $>1700$ \\
\hline Landing altitude, $\mathrm{km}$ & -3.5 & -1.5 & -1.3 & -3.5 & -1.0 \\
\hline Landing ellipse, $\mathrm{km}$ & $420 \times 200$ & $100 \times 50$ & $80 \times 20$ & $75 \times 20$ & $<10 \times 10$ \\
\hline Relative entry velocity, $\mathrm{km} / \mathrm{s}$ & $4.5 / 4.42$ & 7.6 & 5.5 & 5.9 & $>5.5$ \\
\hline Relative entry FPA, deg & -17.6 & -13.8 & -11.5 & -13 & -15.2 \\
\hline $\mathrm{m} / \mathrm{C}_{\mathrm{D}} \mathrm{S}_{\mathrm{ref}}, \mathrm{kg} / \mathrm{m}^{2}$ & 64 & 62 & 90 & 65 & $>140$ \\
\hline Turbulent at peak heating? & No & No & No & No & Yes \\
\hline Peak heat flux, W/cm² & 24 & 115 & 54 & 56 & $>200$ \\
\hline Peak surface pressure, atm & 0.10 & 0.20 & 0.10 & 0.12 & $>0.3$ \\
\hline Heatshield TPS material & SLA-561V & SLA-561V & SLA-561V & SLA-561V & SLA-561V \\
\hline Backshield TPS material & None & SLA-561S & SLA-561S & SLA-561S & SLA-561S \\
\hline Hypersonic $\alpha$, deg & -11 & 0 & 0 & 0 & -16 \\
\hline Hypersonic L/D & 0.18 & 0 & 0 & 0 & 0.24 \\
\hline Control & 3-axis & Spinning & Spinning & 3 -axis & 3-axis \\
\hline Guidance & No & No & No & No & Yes \\
\hline
\end{tabular}

Figure 1.-Mars EDL aeroshell comparison (Ref. 1).

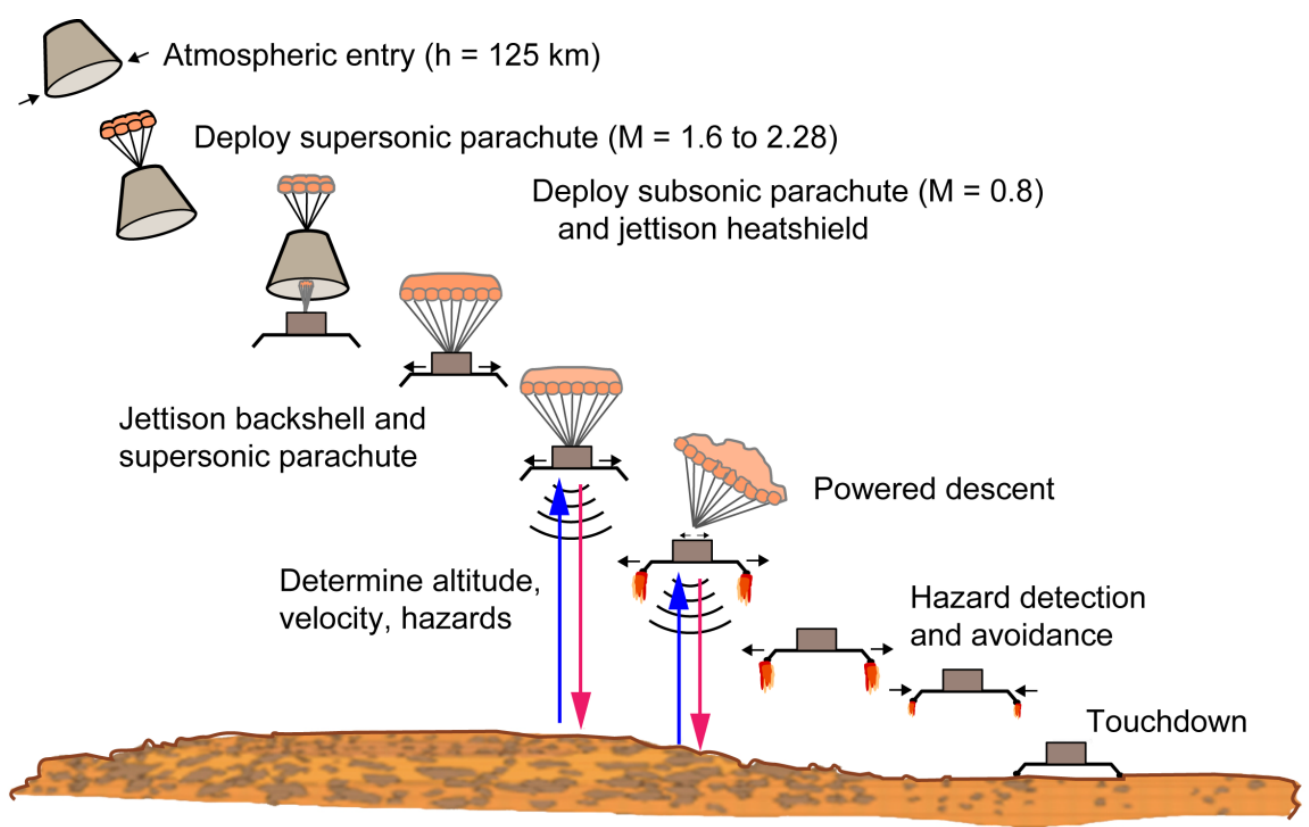

Figure 2.-Mars Science Laboratory EDL sequence (Ref. 2). 

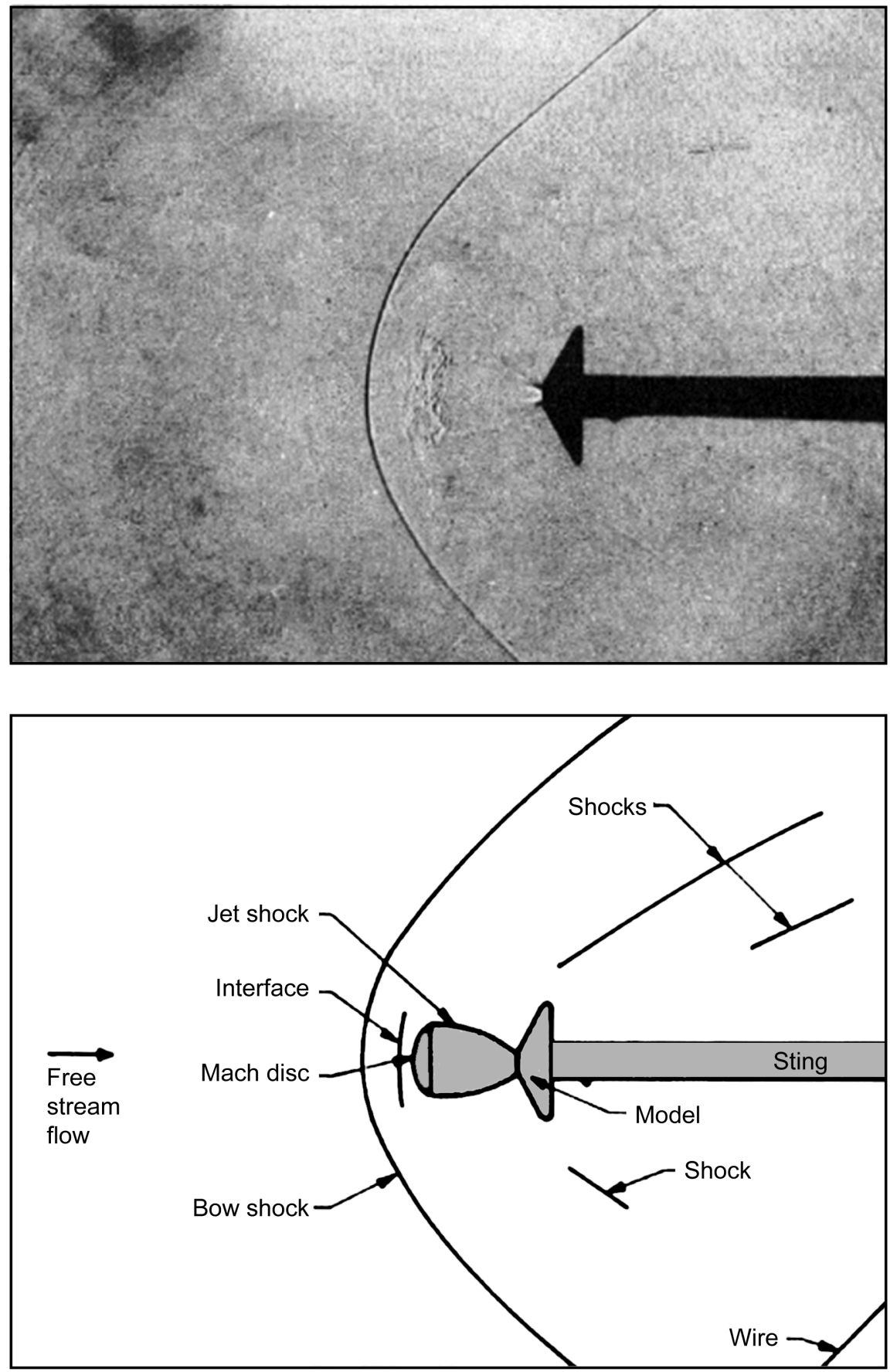

Figure 3.-Retrorocket flow into oncoming supersonic free stream for atmospheric entry (Ref. 3). Single nozzle $60^{\circ}$ aeroshell model with blunt flow interaction, $M_{\infty}=2.0, C_{T}=1.1$ 


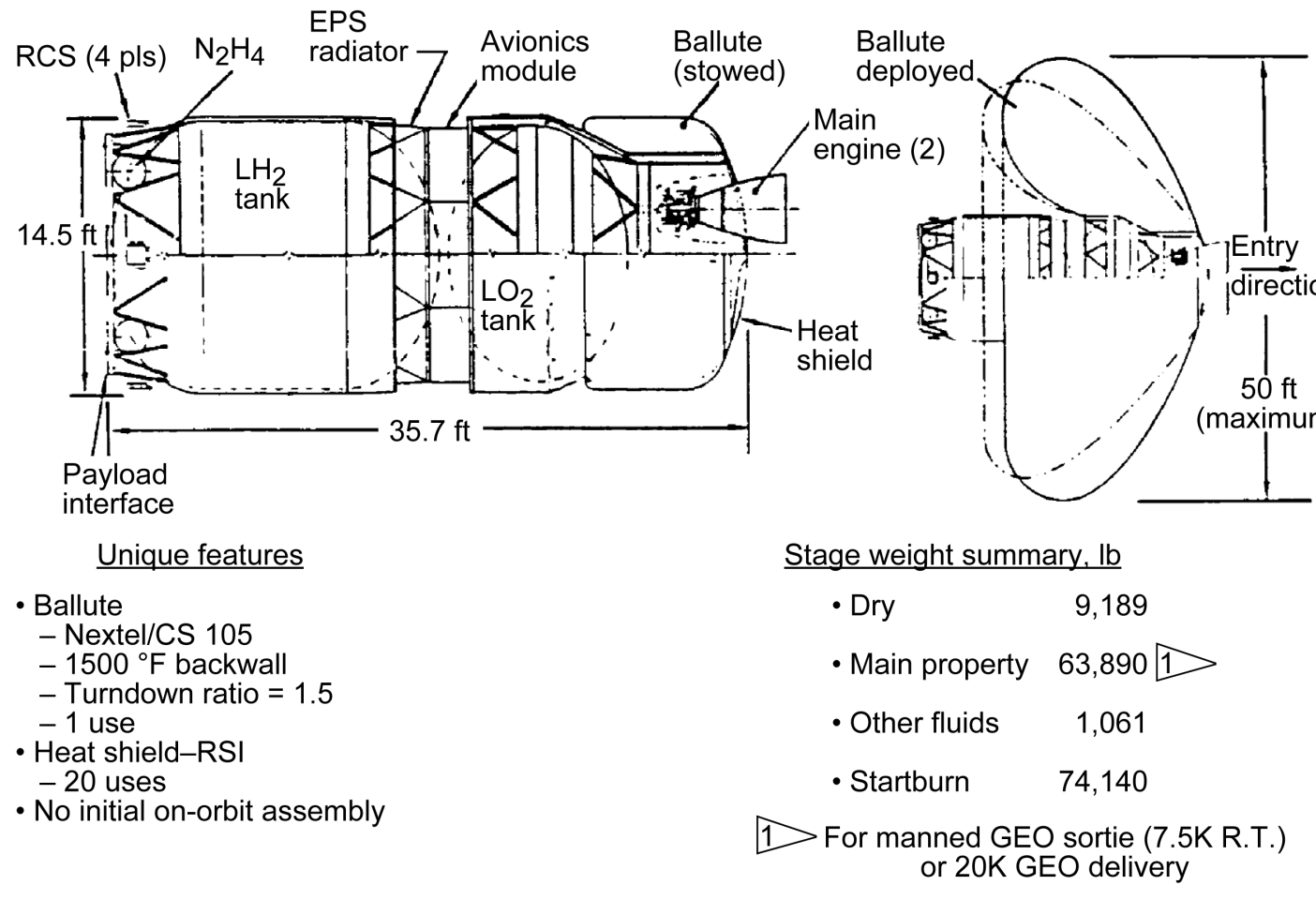

Figure 4.-Space based aerobraking orbital transfer vehicle with inflatable ballute (Ref. 24).

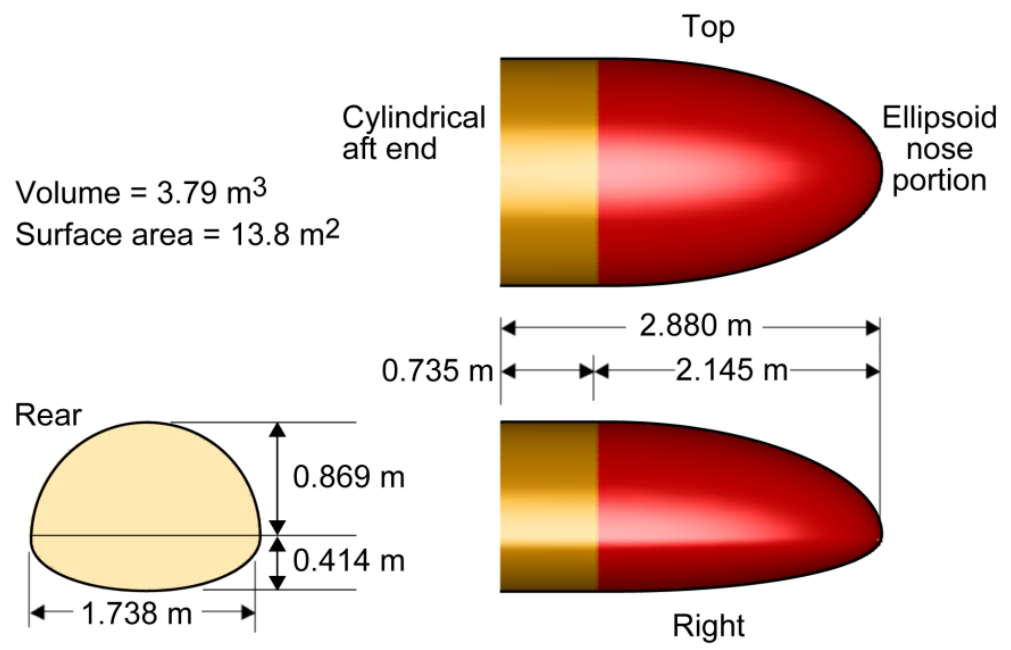

Figure 5.-Ellipsled geometry (Ref. 25). 



\begin{tabular}{|c|c|c|}
\hline \multicolumn{2}{|c|}{ REPORT DOCUMENTATION PAGE } & $\begin{array}{l}\text { Form Approved } \\
\text { OMB No. 0704-0188 }\end{array}$ \\
\hline \multicolumn{3}{|c|}{$\begin{array}{l}\text { The public reporting burden for this collection of information is estimated to average } 1 \text { hour per response, including the time for reviewing instructions, searching existing data sources, gathering and maintaining the } \\
\text { data needed, and completing and reviewing the collection of information. Send comments regarding this burden estimate or any other aspect of this collection of information, including suggestions for reducing this } \\
\text { burden, to Department of Defense, Washington Headquarters Services, Directorate for Information Operations and Reports ( } 0704-01808 \text {, } 1215 \text { Jefferson Davis Highway, Suite } 1224 \text {, Allington, VA } 222202-4302 \text {. } \\
\text { Respondents should be aware that notwithstanding any other provision of law, no person shall be subject to any penalty for failing to comply with a collection of information if it does not display a currently valid OMB } \\
\text { control number. } \\
\text { PLEASE DO NOT RETURN YOUR FORM TO THE ABOVE ADDRESS. }\end{array}$} \\
\hline $\begin{array}{l}\text { 1. REPORT DATE (DD-MM-YYYY) } \\
01-12-2012\end{array}$ & $\begin{array}{l}\text { 2. REPORT TYPE } \\
\text { Technical Memorandum }\end{array}$ & 3. DATES COVERED (From - To) \\
\hline \multirow{3}{*}{\multicolumn{2}{|c|}{$\begin{array}{l}\text { 4. TITLE AND SUBTITLE } \\
\text { Entry, Descent, and Landing With Propulsive Deceleration }\end{array}$}} & 5a. CONTRACT NUMBER \\
\hline & & 5b. GRANT NUMBER \\
\hline & & 5c. PROGRAM ELEMENT NUMBER \\
\hline \multirow{3}{*}{\multicolumn{2}{|c|}{$\begin{array}{l}\text { 6. AUTHOR(S) } \\
\text { Palaszewski, Bryan }\end{array}$}} & 5d. PROJECT NUMBER \\
\hline & & 5e. TASK NUMBER \\
\hline & & $\begin{array}{l}\text { 5f. WORK UNIT NUMBER } \\
\text { WBS 017533.02.02.04 }\end{array}$ \\
\hline \multicolumn{2}{|c|}{$\begin{array}{l}\text { 7. PERFORMING ORGANIZATION NAME(S) AND ADDRESS(ES) } \\
\text { National Aeronautics and Space Administration } \\
\text { John H. Glenn Research Center at Lewis Field } \\
\text { Cleveland, Ohio 44135-3191 }\end{array}$} & $\begin{array}{l}\text { 8. PERFORMING ORGANIZATION } \\
\text { REPORT NUMBER } \\
\text { E-18480 }\end{array}$ \\
\hline \multirow{2}{*}{\multicolumn{2}{|c|}{$\begin{array}{l}\text { 9. SPONSORING/MONITORING AGENCY NAME(S) AND ADDRESS(ES) } \\
\text { National Aeronautics and Space Administration } \\
\text { Washington, DC 20546-0001 }\end{array}$}} & $\begin{array}{l}\text { 10. SPONSORING/MONITOR'S } \\
\text { ACRONYM(S) } \\
\text { NASA }\end{array}$ \\
\hline & & $\begin{array}{l}\text { 11. SPONSORING/MONITORING } \\
\text { REPORT NUMBER } \\
\text { NASA/TM-2012-217745 }\end{array}$ \\
\hline \multicolumn{3}{|c|}{$\begin{array}{l}\text { 12. DISTRIBUTION/AVAILABILITY STATEMENT } \\
\text { Unclassified-Unlimited } \\
\text { Subject Categories: 01, 20, 34, and } 91 \\
\text { Available electronically at http://www.sti.nasa.gov } \\
\text { This publication is available from the NASA Center for AeroSpace Information, 443-757-5802 }\end{array}$} \\
\hline
\end{tabular}

\section{SUPPLEMENTARY NOTES}

\section{ABSTRACT}

The future exploration of the Solar System will require innovations in transportation and the use of entry, descent, and landing (EDL) systems at many planetary landing sites. The cost of space missions has always been prohibitive, and using the natural planetary and planet's moons' atmospheres for entry, descent, and landing can reduce the cost, mass, and complexity of these missions. This paper will describe some of the EDL ideas for planetary entry and survey the overall technologies for EDL that may be attractive for future Solar System missions.

\section{SUBJECT TERMS}

Planetary entry; Propulsion; Rocket engines; Fluid mechanics; Retrorocket; in situe resource utilization

\begin{tabular}{|c|c|c|c|c|c|}
\hline \multicolumn{3}{|c|}{ 16. SECURITY CLASSIFICATION OF: } & \multirow{2}{*}{$\begin{array}{l}\text { 17. LIMITATION OF } \\
\text { ABSTRACT } \\
\text { UU }\end{array}$} & \multirow{2}{*}{$\begin{array}{l}\text { 18. NUMBER } \\
\text { OF } \\
\text { PAGES } \\
18\end{array}$} & \multirow{2}{*}{$\begin{array}{l}\text { 19a. NAME OF RESPONSIBLE PERSON } \\
\text { STI Help Desk (email:help@sti.nasa.gov) } \\
\text { 19b. TELEPHONE NUMBER (include area code, } \\
\text { 443-757-5802 }\end{array}$} \\
\hline $\begin{array}{l}\text { a. REPORT } \\
U\end{array}$ & $\begin{array}{l}\text { b. ABSTRACT } \\
U\end{array}$ & $\begin{array}{l}\text { c. THIS } \\
\text { PAGE } \\
\text { U }\end{array}$ & & & \\
\hline
\end{tabular}



